\title{
EFFECT OF NITROGEN SOURCES AND THEIR LEVEL FOR GROWTH, YIELD AND QUALITY OF GUAVA (Psidiumgujava L)
}

\author{
BIBHA KUMARI, SURAJ PRAKASH, U S JAISWAL \& M. D. FEZA AHMAD
}

Department of Horticulture (Fruit \& Fruit Tech) Bihar Agricultural College, Sabour, Bhagalpur, Bihar

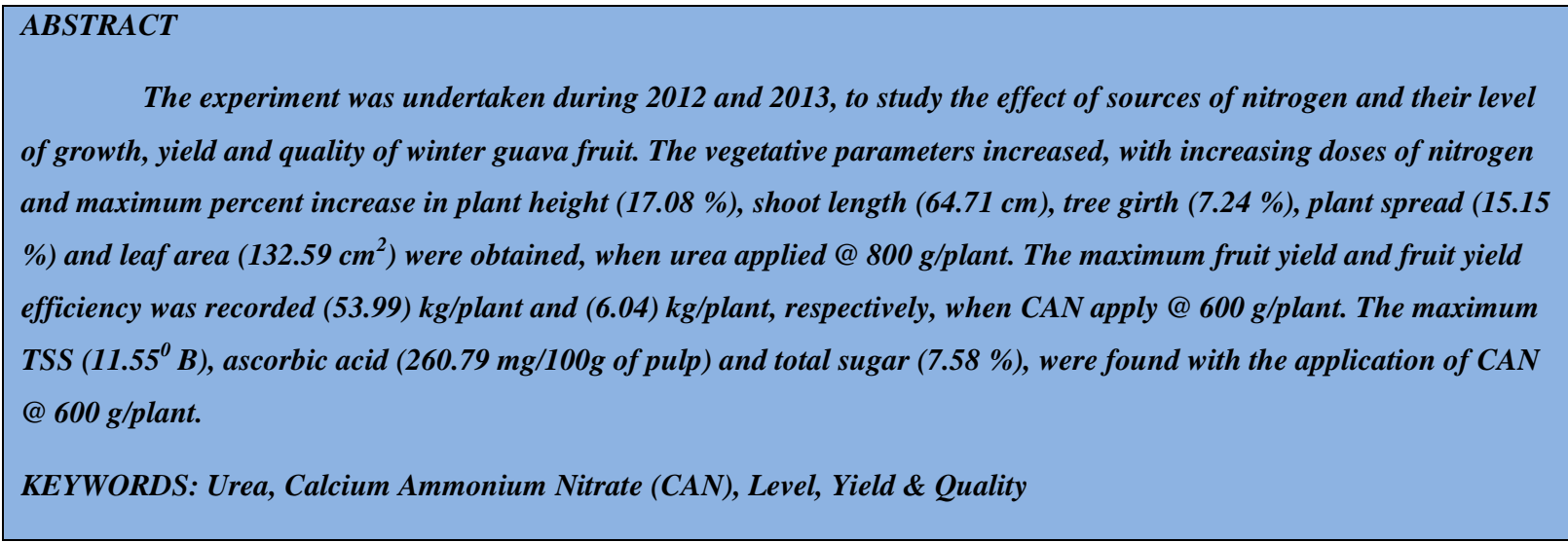

Received: Sep 23, 2017; Accepted: Oct 18, 2017; Published: Oct 26, 2017; Paper Id: IJASRDEC201711

\section{INTRODUCTION}

Guava (PsidiumguajavaL) belongs to the family of Myrtaceae and native to tropical America. It is being grown commercially in the tropics, as well as subtropical parts of all over the world. As an important crop of India, it has gained considerable prominence on account of its high nutritive value, availability of moderate price, a pleasant aroma and good flavour, so that, it is called as 'apple of tropics'. Nutrients are essential for the productivity and quality of guava fruits. Hence, determination of nutritional needs for efficient production of high quality fruits is an important aspect of nutrient management, for the orchardists. Nitrogen imparts vigorous vegetative growth and essentials, for carbohydrate utilization within plants. The experiment was formulated, to assess the sources of nitrogen and their level of growth, yield and quality of guava.

\section{MATERIALS AND METHODS}

The investigations were carried out at the Bihar Agricultural College, Sabour, Bhagalpur, during the winter season of the year 2012 and 2013. The experiment was conducted on nine years old plants of guava cv. 'Allahabad Safeda', during winter season. Sabour is situated under subtropical zone, between $25^{\circ} 15^{\prime} 40$ " north altitudes and $87^{\circ} 12$ ' 42 " east longitudes, at an altitude of 45.72 meters, above mean sea level. It has a semi-arid, subtropical climate with hot desiccating summer, cold, but frostless winter with an average rainfall about $1040 \mathrm{~mm}$. The soil of an orchard is loam, deep and well drained. The fertility status of the soil was ascertained by its chemical analysis. Nitrogen sources were used from urea and calcium ammonium nitrate (CAN) and their levels of nitrogen applied (a.i) @ 400, 600 \& 800 g/plant. Phosphorous and potassium applied uniformly in all the treatments. The $2 / 3^{\text {rd }}$ and $1 / 3^{\text {rd }}$ dose of nitrogen applied during the last week of June and September, respectively. The experiment was laid out in Randomized Block Design (Factorial), replicated thrice. The height of the tree was measured in meter from 
the ground surface to top of the tree, with the help of a scaled bamboo pole. New vegetative shoots of individual branch, in all the directions, i.e., East, West and North- South were tagged and measured, with the help of measuring tape. The yield of fruits per plant was recorded by weighing the harvested fruits, in different pickings. Fruits yield efficiency was recorded, by weighing fruits in a square meter in different pickings. The total soluble solids of the fruit juice were estimated with the help of a hand refractometer and expressed as ${ }^{0} \mathrm{~B}$. Ascorbic acid in guava determined and titrated against 2, 6dichlorophenol indophenol dye solution, to a faint pink end point which persisted for 15 seconds (A. O. A. C., 1984). The vitamin $\mathrm{C}$ content of the fruit was expressed as milligrams of ascorbic acid, per $100 \mathrm{~g}$ of pulp. Total sugars were determined by the method of Lane and Eyon (1923).

\section{RESULTS AND DISCUSSION}

Sources of Nitrogen and its level of application to guava plant showed beneficial effect on vegetative growth parameters. Perusal of data presented in Table-1 indicated that, plant height, length of shoots, plant girth and the plant spread increased with increasing levels of nitrogen. Significantly, maximum plant height (17.08\%), shoot length (64.71 $\mathrm{cm})$, tree girth $(7.24 \%)$ and a plant spread $(15.15 \%)$ was recorded with the application of $800 \mathrm{~g}$ Nitrogen /plant. The effect of doses of urea was more pronounced, compared to calcium ammonium nitrate on vegetative growth parameters. Minimum plant height, shoot length, tree girth and plant spread were recorded under nitrogen applied @ 400 g/plant. It was observed that, increasing levels of nitrogen increased the vegetative parameters in a progressive manner. Similar findings were reported by Pathak and Ram (2005), Singh et al (2001), and Aseri et al (2008).

Table 1: Effect of Nitrogen and its Levels on Vegetative Parameters of Guava Plant (Pooled Data Two Years)

\begin{tabular}{|l|c|c|c|c|}
\hline \multicolumn{1}{|c|}{ Doses of Nitrogen } & $\begin{array}{c}\text { \% Increase in } \\
\text { Plant Height }\end{array}$ & $\begin{array}{c}\text { Length of } \\
\text { Shoots }(\mathbf{c m})\end{array}$ & $\begin{array}{c}\text { \% Increase in } \\
\text { Plant Girth }\end{array}$ & $\begin{array}{c}\text { \% Increases in } \\
\text { Plant Spread }\end{array}$ \\
\hline Nitrogen @ 400 g/plant & 9.01 & 42.74 & 6.75 & 8.78 \\
\hline Nitrogen @ 600 g/plant & 14.70 & 53.95 & 6.97 & 12.72 \\
\hline Nitrogen @ 800 g/plant & 17.08 & 64.71 & 7.24 & 15.15 \\
\hline SE \pm m & 0.07 & 0.36 & 0.04 & 0.09 \\
\hline C D at 5\% & 0.22 & 1.04 & 0.13 & 0.25 \\
\hline
\end{tabular}

Table 2: Effect of Sources of Nitrogen on Vegetative Parameters of Guava (Pooled Data Two Years)

\begin{tabular}{|l|c|c|c|c|}
\hline $\begin{array}{c}\text { Effect of } \\
\text { Sources } \\
\text { Nitrogen }\end{array}$ & $\begin{array}{c}\text { \% Increase in } \\
\text { Plant Height }\end{array}$ & $\begin{array}{c}\text { Length of } \\
\text { Shoots }(\mathbf{c m})\end{array}$ & $\begin{array}{c}\text { \% Increase in } \\
\text { Plant Girth }\end{array}$ & $\begin{array}{c}\text { \% Increases in } \\
\text { Plant Spread }\end{array}$ \\
\hline Urea & 13.86 & 55.35 & 7.05 & 12.35 \\
\hline Calcium nitrate & 13.33 & 52.25 & 6.92 & 12.08 \\
\hline SE $\pm m$ & 0.09 & & 0.05 & 0.10 \\
\hline C D at 5\% & 0.26 & NS & 0.15 & 0.28 \\
\hline
\end{tabular}

The data pertaining to sources of nitrogen, compared among Urea and Calcium Ammonium Nitrate (CAN) in Table-2. The data clearly revealed that, Urea is having a more pronounced effect on vegetative parameter. Maximum plant height $(13.86 \%)$, length of shoots $(55.35 \mathrm{~cm})$ plant girth $(7.05 \%)$ and a plant spread $(12.35 \%)$ was observed, in urea than CAN. Application of fertilizer through urea is more readily available to the plant. The results of the present study are in accordance with Pathak and Ram, 2005. They observed improvement of vegetative growth parameters in guava, with the application of different fertilizers. The percent increase in tree height, spread, shoot length and leaf area could be attributed to increased nutrient availability and hence, vigorous plant growth is attained. Singh et al 2001 and Aseriet al 2006 
Table 3: Effect of Nitrogen and its Levels on Yield Contributing Parameters of Guava Plant (Pooled Data Two Year)

\begin{tabular}{|l|c|c|c|c|}
\hline \multicolumn{1}{|c|}{ Doses of Nitrogen } & Fruit Set (\%) & Days of Harvest /Maturity & Fruit Drop (\%) & Yield (Kg/Plant) \\
\hline Nitrogen @ 400 g/plant & $66.52(54.73)$ & 108.92 & 41.22 & 43.14 \\
\hline Nitrogen @ 600 g/plant & $70.46(57.20)$ & 103.14 & 39.21 & 52.89 \\
\hline Nitrogen @ 800 g/plant & $69.77(56.79)$ & 102.61 & 37.43 & 47.78 \\
\hline SE \pm m & 0.25 & 2.01 & 0.18 & 0.35 \\
\hline C D at 5\% & 0.70 & 0.71 & 0.52 & 0.99 \\
\hline
\end{tabular}

Perusal of data from Table: -3 showed that, Nitrogen has a significant effect on fruit set percent, days of harvesting; fruit drop percent and yield. Significantly, higher yield (52.89 kg/plant) and fruit set (70.46\%) were obtained, when nitrogen was applied @ 600 g/plant. Whereas, least number of days for harvesting, i.e., 102.61 days and minimum fruit drop (37.43\%) were noticed, when nitrogen was applied @ 800 g/plant, which is statistically similar with application of nitrogen @ $600 \mathrm{~g} / \mathrm{plant}$. The number of days for harvesting reduces by one week. Soil application of Nitrogen leads to early flowering might be, due to synthesis of nucleic acid, which in turn influenced the formation of flower bud primordial, advanced the completion of physiological process involved in blossoming. The results of present finding are in support with Amitkumar Goswami et al., 2012 and Akashsharma et al., 2013

The graph, 1 pertaining to fruit yield and fruit yield efficiency was depicted. It indicated that, fruit yield increased with enhancing doses of nitrogen from its sources. Significantly, maximum fruit yield (53.99 kg/plant), fruit set (69.71\%) and fruit yield efficiency $(6.01 \mathrm{~kg} / \mathrm{m} 2)$, least number of days (102.78 days) and fruit drop (36.92\%) were recorded, due to application of CAN @ 600 g/plant, which was followed by application of urea @ 600 g/plant. A $20.70 \%$ increase in fruit yield, over the lowest dose of nitrogen (urea @ $400 \mathrm{~g} / \mathrm{plant}$ ). In terms of yield, calcium ammonium nitrate gave better results than urea. The above results are in accordance with the finding of Athani et al (2009) and Dinesh Kumar et al (2009).



Graph 1: Effect of Sources of Nitrogen on Reproductive Parameters of Guava (Pooled Data Two Years)

Table 4: Effect of Nitrogen and its Levels of Quality Contributing Parameters of Guava Plant (Pooled Data Two Years)

\begin{tabular}{|l|c|c|c|}
\hline \multicolumn{1}{|c|}{ Effect of Nitrogen } & TSS $\left({ }^{\mathbf{0}} \mathbf{B}\right)$ & Ascorbic Acid (mg/100 g of Pulp) & Total Sugar (\%) \\
\hline Nitrogen @ 400 g/plant & 10.07 & 233.76 & 6.00 \\
\hline Nitrogen @ 600 g/plant & 11.55 & 260.79 & 7.58 \\
\hline Nitrogen @ 800 g/plant & 11.17 & 261.64 & 7.21 \\
\hline SE \pm m & 0.06 & 1.15 & 0.03 \\
\hline C D at 5\% & 0.19 & 3.24 & 0.09 \\
\hline
\end{tabular}


The data pertaining to fruit quality characters, as influenced by nitrogen and its level have been presented in Table -4. The TSS, ascorbic acid and total sugar increased, with increasing levels of nitrogen from $400 \mathrm{~g}$ to $800 \mathrm{~g} /$ tree, being the maximum with the application of $600 \mathrm{~g}$ nitrogen/tree. Significantly, maximum TSS $\left(11.55^{0} \mathrm{~B}\right)$, ascorbic acid (260.79 $\mathrm{mg} / 100 \mathrm{~g}$ of pulp) and total sugar (7.58 \%) were found, with nitrogen @ $600 \mathrm{~g} / \mathrm{plant}$. However, minimum TSS, ascorbic acid and total sugar were observed, when nitrogen applied @ $400 \mathrm{~g} / \mathrm{plant}$.

Table 5: Effect of Sources of Nitrogen on Quality Contributing Parameters of Guava Plant (Pooled Data Two Years)

\begin{tabular}{|l|c|c|c|}
\hline Effect of Sources Nitrogen & T S S (* Brix) & Ascorbic Acid (mg /100 g of Pulp) & Total Sugar (\%) \\
\hline Urea & 10.83 & 247.23 & 6.78 \\
\hline Calcium nitrate & 12.02 & 256.90 & 8.08 \\
\hline SE \pm m & ---- & 1.31 & 0.03 \\
\hline C D at 5\% & NS & 3.71 & 0.10 \\
\hline
\end{tabular}

Perusal of data on fruit quality characters, as influenced by sources of nitrogen have been presented in Table -5 The TSS, ascorbic acid and total sugar increased with sources of nitrogen, from $400 \mathrm{~g}$ to $800 \mathrm{~g} / \mathrm{plant}$, being the maximum with the application of $600 \mathrm{~g}$ calcium nitrate /plant. Significantly, maximum TSS (12.02* B), ascorbic acid (256.90 mg/100 g of pulp) and total sugar ( $8.08 \%$ ) were found with CAN @ $600 \mathrm{~g} / \mathrm{plant}$. However, minimum TSS, ascorbic acid and total sugar were observed, when Urea applied @ 400 g/plant. The effect of doses of calcium ammonium nitrate on yield contributing characters and quality parameters was more pronounced compared to urea. The findings are in conformity with Hundal et al (2007), Hari et al (2008) and Kumar et al (2009).

\section{CONCLUSIONS}

Application of Urea @ $800 \mathrm{~g} /$ plant had a more pronounced effect on vegetative growth, rather than reproductive parameters. From the above depicted table and graph, it is found that, the calcium nitrate @ $600 \mathrm{~g} / \mathrm{plant}$ is the best for improving yield contributing character, as well as yield and quality attributes of guava fruits.

\section{REFERENCES}

1. A. O. A. C (1984) Official method of analysis (14 $4^{\text {th }}$ Ed.) Association of Official Agricultural Chemistry, Washington, D. C., pp.16.

2. Aseri, G. K.; N. jain., J. Panwar., A. V. Rao and P. R. Meghwal (2008) Biofertlilzers improves plant growth, fruit yield, nutrition metabolism and rhizosphere enzyme activates of pomegranate ( Punicagranatum L ) in Indian Thar desert. Scientia Hort. 117:130-135.

3. Athani, S. I; Revanappa and T. B. Allollt (2009) Influence of organic and inorganic fertilizers on growth, fruit characters, nutrient content and yield in guava. J. of Ecobiol.26: 131-138.

4. Dinesh Kumar, V. Pandey, K. Anjaneyulu and Vishal Nath (2009). Optimization of major nutrients of guava yield and quality under east coastal conditions. Indian J. of Hort. 66 (1): 18-21.

5. Raji.T.N. Al-Zamily et al., Production of Single Cell Oil by Local Isolate of Mucor Species Using By-Products as Carbon and Nitrogen Sources and Determination of Fatty Acids Profile, International Journal of Agricultural Science and Research (IJASR), Volume 6, Issue 1, January - February 2016, pp. 309-320

6. Hari, B; Y. Rajesh and R. Dwivedi (2008). Effect of INM on growth, yield, yield attributing characters and quality of guava (Psidiumguajava L.) cv. Sardar. 
7. Hundal, H. S; Dhanwinder Singh and Kuldip Singh (2007). Monitoring nutrient status of guava fruit trees in Punjab. North West India through the diagnostic and recommendation integrated system approach. Communication in Soil Sci. and Plant Anal.38 (15/16): 2117-2130.

8. Kumar. O., V. Pandey., K. Anganeyulu and Vishal Nath (2009) Optimization of major nutrients for guava yield and quality under east coastal conditions. Indian J. Hort. 66; (1): 18-21.

9. Lane, J. H. and I. Eyon (1923) Determination of sugar by Fehling's solution with methylene as indicator. J. Soc. Chem. Ind.,42: 32

10. Pathak, R. K. and R. A. Ram (2005) Integration of organic farming practices for sustainable production of guava. In: First International guava Symposium, 4-5 Dec, 2005, CISH Lucknow, India P 144-45.

11. Singh, H. K.; A. K. Srivastava; R. Dwivedi and P. Kumar (2001). Effect of foliar feeding of micronutrients on plant growth, fruit quality, yield and internal fruit necrosis of aonla (EmblicaofficinalisGaertn.) cv. Francis. Prog. Hort., 33 (1): 80-83.

12. Singh, N. P. and C. B. S. Rajput (1977). Chemical composition of guava (Psidiumguajava L.) fruit as influenced by nitrogen application. Prog. Hort., 9 (2): 67-70. 
